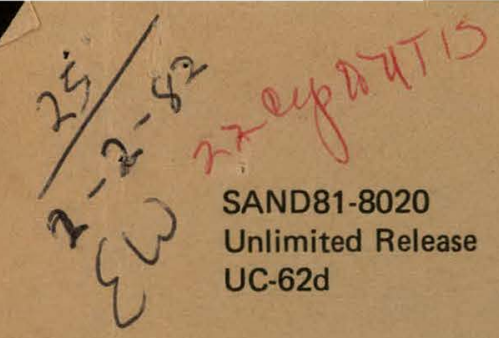

$$
I-1208
$$

\title{
MASTER
}

\section{Industrial Use of Molten Nitrate/Nitrite Salts}

\author{
R. W. Carling, R. W. Mar
}

Prepared hy Sandia National Laboratories, Albuquerque, New

Mexico 87185 and Livermore, California 94550 for the United

States Department of Energy under Contract DE-AC04-76DP00789.

Printed December 1981

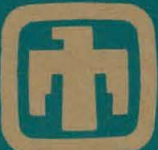

Sandia National Laboratories

\section{energy report}
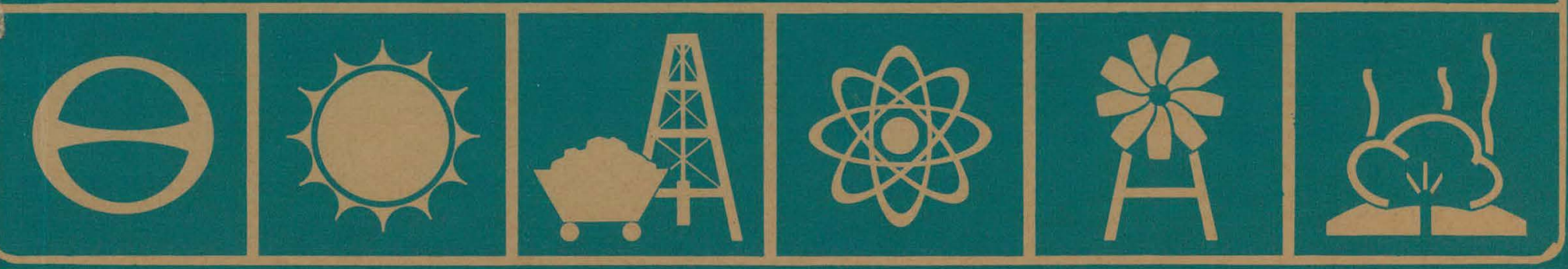


\section{DISCLAIMER}

This report was prepared as an account of work sponsored by an agency of the United States Government. Neither the United States Government nor any agency Thereof, nor any of their employees, makes any warranty, express or implied, or assumes any legal liability or responsibility for the accuracy, completeness, or usefulness of any information, apparatus, product, or process disclosed, or represents that its use would not infringe privately owned rights. Reference herein to any specific commercial product, process, or service by trade name, trademark, manufacturer, or otherwise does not necessarily constitute or imply its endorsement, recommendation, or favoring by the United States Government or any agency thereof. The views and opinions of authors expressed herein do not necessarily state or reflect those of the United States Government or any agency thereof. 


\section{DISCLAIMER}

Portions of this document may be illegible in electronic image products. Images are produced from the best available original document. 

of Energy by Sandia Corporation.

\section{NOTICE}

This report was prepared as an account of work sponsored by the United States Government. Neither the United States nor the United States Department of Energy, nor any of their employees, nor any of their contractors, subcontractors, or their employees, makes any warranty, express or implied, or assumes any legal liability or responsibility for the accuracy, completeness or usefulness of any information, apparatus, product or process disclosed, or represents that its use would not infringe privately owned rights.

Printed in the United States of America Available from National Technical Information Service U. S. Department of Commerce 5285 Port Royal Road Springfield, VA 22161

Price: Printed Copy $\$ 4.50$; Microfiche $\$ 3.00$ 


\section{PAGES 1 to 2 WERE INTENTIONALLY LEFT BLANK}


SAND81-8020

$u C-62 d$

Unl imited Release

Printed December 1981

INDUSTRIAL USE OF MOLTEN NITRATE/NITRITE SALTS

R. W. Carling

Thermal Subsystems Division

SAND $--81-8020$

DE82 010032

R. W. Mar

Exploratory Chemistry Division I

Sandia National Laboratories, Livermore

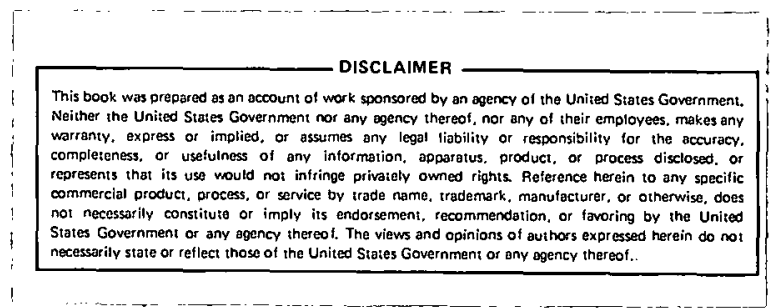

\section{ABSTRACT}

Nitrate salts have been used for years as a high-temperature heat transfer medium in the chemical and metal industries. This experience is often cited as an argument for the use of these salts in large-scale solar energy systems. However, this industrial experience has not been well documented and this study was carried out to provide such information to the solar community and to determine the applicability of this data base. Seven different industrial plants were visited and the plant operators were interviewed w1 th regard to operating history and experience. In all cases the molten salt systems operate without problems. However, it is not possible to apply the base of industrial experience directly to solar thermal energy applications because of differences in operating temperature, salt composition, alloys used, and thermal/mechanical conditions. 


\section{ACKNOWLEDGMENT}

We wish to thank the following for their cooperation in discussing the use of molten nitrate salts: Charlie Frledbery of Monsanto, Gerry Baier of Reichold Chemical, Jim Heard and John Caldwell of 01 in Chemical, Bob Reinberg of McDonnell Douglas, and Sam Robinson of Intenco. The information on the melamine plant was obtained from Dave Beshore of Martin Marietta Corporation. 
CONTENTS

Introduction

Page

Phthalic Anhydride Production - Monsanto Plant

Process Description

14

Plant Operation

14

Salt

Containment Materials

Maleic Anhydride - Reichold Chemical

Process Description

Plant Operation

Salt

Containment Materials

Sodium Nitrate - 01 in Chemical

Process Description

Plant Operation

Salt

Containment Materials

Caustic Concentrator - 0lin Chemical 20

Process Description 20

Plant Operation $\quad 22$

Salt

Containment Materials

Melamine - Anonymous

Process Description

Plant Operation

Salt

Containment Materials

Metals Treating - McDonnell Douglas

Process Description 
Others

Application of Industrial Experience to Solar Systems

REFERENCES 


\section{ILLUSTRATIONS}

Page

1 Circulating Molten Salt System for Heat Removal from an Exothermic Chemical Reactor

2 Portion of a $\mathrm{NaNO}_{3}$ Synthesis Plant

3 Caustic Concentration System Using a Pumped Molten Salt

TABLES

Page

I Examples of Industrial Firms Using or Having Used Molten 12 Nitrate/Nitrite Salts

11 Summary of Mul leil Salt Usage at Plants Visited 


\section{INDUSTRIAL USE OF MOLTEN NITRATE/NITRITE SALTS}

\section{Introduction}

Molten nitrate salts have received considerable attention in the solar community as a potential heat transfer and thermal energy storage medium. 1,2 Nitrate salts have been used for years as a high-temperature heat transfer inedium in the chemical and metal industries, and this experience is often cited as an argument for the use of these salts in large-scale commercial solar energy systems. However, this industrial experience has not been well documented. This study was carried out to provide such information to the solar community and to determine the applicability of this base data. Details regarding equipment, hardware and plant design will not be discussed here and the reader is referred to previous publications $3-6$ for this information. The emphasis of this report is on user experience, plant performance and plant history.

A number of molten nitrate salt users were contacted and seven plants were selected to be visited. Discussions with plant managers and plant operators were carried out during on-site inspections. The uses of molten nitrate salts can be grouped into those providing heat to or removing heat from a chemical reaction and metal heat treating. Table $I$ is a sample of industries employing molten nitrates and nitrites for the above purposes. While it is not an exhaustive list, it does show how extensive the use of mol ten nitrates and nitrites is. 


\section{TABLE I}

EXAMPLES OF INDUSTRIAL FIRMS USING OR HAVING USED MOLTEN NITRATE/NITRITE SALTS

\begin{tabular}{|c|c|c|c|}
\hline Company & Process & Company & Process \\
\hline $\begin{array}{l}\text { Reichold Chem. } \\
\text { Morris, IL } \\
\text { Elizabeth, NJ }\end{array}$ & $\begin{array}{l}\text { maleic } \\
\text { anhydride }\end{array}$ & $\begin{array}{l}\text { Koppers } \\
\text { Pittsburgh, PA } \\
\text { Chicago, IL }\end{array}$ & $\begin{array}{l}\text { phthal ic } \\
\text { anhydride }\end{array}$ \\
\hline $\begin{array}{l}\text { Aenka Chem. } \\
\text { Houston, TX }\end{array}$ & $\begin{array}{l}\text { maleic } \\
\text { annydride }\end{array}$ & $\begin{array}{l}\text { U.S. Steel } \\
\text { Neville Island, PA }\end{array}$ & $\begin{array}{l}\text { phthalic } \\
\text { anhydride. }\end{array}$ \\
\hline $\begin{array}{l}\text { Ashl and Chem. } \\
\text { Col umbus, } \mathrm{OH}\end{array}$ & $\begin{array}{l}\text { maleic } \\
\text { anhydride }\end{array}$ & $\begin{array}{l}\text { Monsanto } \\
\text { Glen Burnie, MD } \\
\text { Texas City, TX }\end{array}$ & $\begin{array}{l}\text { phthalic } \\
\text { anhydride }\end{array}$ \\
\hline $\begin{array}{l}\text { Celanese Corp. } \\
\text { Seabrook, TX }\end{array}$ & $\begin{array}{l}\text { various } \\
\text { organics }\end{array}$ & $\begin{array}{l}\text { Hooker Chem. } \\
\text { Houston, TX }\end{array}$ & $\begin{array}{l}\text { phthal ic } \\
\text { anhydride }\end{array}$ \\
\hline $\begin{array}{l}\text { Am. Cyanamid } \\
\text { Avondale, LA }\end{array}$ & mel amine & $\begin{array}{l}\text { BASF-Wyandotte } \\
\text { S. Kearney, NJ } \\
\text { Wyandotte, MI }\end{array}$ & $\begin{array}{l}\text { phthal ic } \\
\text { anhydride }\end{array}$ \\
\hline $\begin{array}{l}\text { Am. Cyanamid } \\
\text { Charlotte, NC }\end{array}$ & $\begin{array}{l}\text { various } \\
\text { organics }\end{array}$ & $\begin{array}{l}\text { P.P.G. } \\
\text { Natrium, WV }\end{array}$ & caustic \\
\hline $\begin{array}{l}\text { Melamine Corp. } \\
\text { Donaldsville, LA }\end{array}$ & mel amine & $\begin{array}{l}\text { Catalytic, Inc. } \\
\text { Charlotte, NC }\end{array}$ & $\begin{array}{l}\text { various } \\
\text { organics }\end{array}$ \\
\hline $\begin{array}{l}\text { Chevron } \\
\text { Richmond, CA }\end{array}$ & $\begin{array}{l}\text { phthalic } \\
\text { anhydride }\end{array}$ & $\begin{array}{l}\text { Dow Chemical } \\
\text { Midl and, MI }\end{array}$ & caustic \\
\hline $\begin{array}{l}\text { Mall inckrodt } \\
\text { St. Louis, MO }\end{array}$ & $\begin{array}{l}\text { various } \\
\text { organics }\end{array}$ & $\begin{array}{l}\text { McDonnell Douglas } \\
\text { Tulsa, OK }\end{array}$ & $\begin{array}{l}\text { Al solution } \\
\text { treating }\end{array}$ \\
\hline $\begin{array}{l}\text { Stauffer } \\
\text { Westport, CT }\end{array}$ & $\begin{array}{l}\text { sulfur, } \\
\text { caustic }\end{array}$ & $\begin{array}{l}\text { Dehaviland Aircraft } \\
\text { Toronto, Ont. }\end{array}$ & $\begin{array}{l}\text { Al solution } \\
\text { treating }\end{array}$ \\
\hline $\begin{array}{l}\text { Roll Forming } \\
\text { Shelbyville, KY }\end{array}$ & $\begin{array}{l}\text { Al solution } \\
\text { treating }\end{array}$ & $\begin{array}{l}\text { Material Processing } \\
\text { Toronto, Oní. }\end{array}$ & $\begin{array}{l}\text { Al solution } \\
\text { treating }\end{array}$ \\
\hline $\begin{array}{l}\text { Piper Industries } \\
\text { New Albany, MS }\end{array}$ & $\begin{array}{l}\text { Al solution } \\
\text { treating }\end{array}$ & $\begin{array}{l}\text { Beneke Wire Co. } \\
\text { Louisville, KY }\end{array}$ & $\begin{array}{l}\text { solution } \\
\text { treating }\end{array}$ \\
\hline $\begin{array}{l}01 \text { in Chem. } \\
\text { Charleston, TN } \\
\text { Lake Charles, LA }\end{array}$ & $\begin{array}{l}\text { caustic } \\
\mathrm{NaNO}_{3}\end{array}$ & $\begin{array}{l}\text { Intenco } \\
\text { Houston, TX }\end{array}$ & $\begin{array}{l}\text { carbon } \\
\text { black }\end{array}$ \\
\hline
\end{tabular}


Seven different plants using molten nitrate salts were visited: (1) phthalic anhydride production, Monsanto, Texas City, Texas, (2) maleic anhydride production, Reichold Chemical Company, Elizabeth, New Jersey, (3) $\mathrm{NaNO}_{3}$ production, 01 in Chemical Corporation, Lake Charles, Louisiana, (4) $\mathrm{NaOH}$ concentration, 01 in Chemical Corporation, Charleston, Tennessee, (5) melamine production, anonymous, (6) al uminum alloy heat treating, McDonnell Douglas, Tulsa, Oklahoma, and (7) carbon black production, Intenco, Incorporated, Houston, Texas. A brief summary of the plant characteristics is given in Table II.

TABLE II

SUMMARY OF MOLTEN SALT USAGE AT PLANTS VISITED

\begin{tabular}{|c|c|c|c|c|}
\hline Plant & Salt & $\begin{array}{l}\text { Maximum } \\
\text { Temp }\left({ }^{\circ} \mathrm{C}\right)\end{array}$ & $\begin{array}{c}\text { Construction } \\
\text { Materials }\end{array}$ & $\begin{array}{l}\text { Years of } \\
\text { Operation }\end{array}$ \\
\hline $\begin{array}{l}\text { Monsanto } \\
\text { phthalic anhydride } \\
\text { Texas City, TX }\end{array}$ & HITEC* & 480 & Carbon Steel & 9 \\
\hline $\begin{array}{l}\text { Reichold Chem. } \\
\text { maleic anhydride } \\
\text { Elizabeth, NJ }\end{array}$ & $\mathrm{NaNO}_{2} / \mathrm{KNO}_{3}$ & 450 & Carbon Steel & 19 \\
\hline $\begin{array}{l}01 \text { in Chem. } \\
\mathrm{NaNO}_{3} \text { production } \\
\text { Lake Charles, LA }\end{array}$ & $\mathrm{NaNO}_{3}$ & 450 & $\begin{array}{l}\text { Carbon Steel } \\
\text { 304L } \\
310\end{array}$ & 30 \\
\hline $\begin{array}{l}01 \text { in Chein. } \\
\text { caustic conc. } \\
\text { Charleston, TN }\end{array}$ & HITEC* & 425 & $\begin{array}{l}\text { Carbon Steel } \\
\text { IN600 }\end{array}$ & 7 \\
\hline $\begin{array}{l}\text { Anonymous } \\
\text { mel amine }\end{array}$ & HITEC* & 450 & $\begin{array}{l}\text { Carbon Steel } \\
\text { Hastelloy } 6\end{array}$ & 10 \\
\hline $\begin{array}{l}\text { McDonnell Douglas } \\
\text { metals treating } \\
\text { Tulsa, OK }\end{array}$ & Drawsalt*夫 & 495 & Carbon Steel & 30 \\
\hline $\begin{array}{l}\text { Intenco } \\
\text { carbon black } \\
\text { Houston, TX }\end{array}$ & HITEC* & 550 & 304 & $1-1 / 2$ \\
\hline $\begin{array}{l}{ }^{\star} 40 \text { percent } \mathrm{NaNO}_{2}, \\
{ }^{*} 46 \text { percent } \mathrm{NaNO}_{3},\end{array}$ & \multicolumn{4}{|c|}{$\begin{array}{l}7 \text { percent } \mathrm{NaNO}_{3}, 53 \text { percent } \mathrm{KNO}_{3} \text { by weight. } \\
54 \text { percent } \mathrm{KNO}_{3} \text { by weight. }\end{array}$} \\
\hline
\end{tabular}


Each plant is treated individually in the discussion below. A brief description of the plant process is given, followed by a discussion of the plant history and operating schedule. Details of the salt fluid are given with an emphasis on salt chemistry, its measurement and maintenance; materials of construction are identified and problems with corrosion discussed. Our comments and observations are specific to the plants we visited; however, they are probably representative of other plants in the same industry.

\section{Phthalic Anhydride Production - Monsanto Plant}

\section{Process Description}

Phthalic anhydride is an organic compound used in the manufacture of plasticizers, alkyd resins, and polyesters. The two commonly used synthesis routes are the air oxidation of naphthalene or orthoxylene; both are highly exothermic catalyzed-gas phase reactions.

The basic features of the circulating molten salt system used in the synthesis of phthalic anhydride are shown in Figure 1. The reactor is a shell and tube heat exchanger with catalyst pellets loaded in the tubes. The reactant gases (air and naphthalene, or air and orthoxylene) enter the tubes from the bottom and product gases exit at the top. The molten salt flows in the opposite direction of the reactant/product gas stream on the shell side of the tubes. The salt is held in a holding tank where it is pumped to the top of the shell and tube reactor. It enters the reactor at $\sim 300^{\circ} \mathrm{C}$ and exits at $<480^{\circ} \mathrm{C}$. The hot salt then flows through another heat exchanger to generate $235^{\circ} \mathrm{C} / 450 \mathrm{psia}$ steam at rates of $12,000-16,000 \mathrm{lb} / \mathrm{hr}$. The salt exits the steam generator at $\sim 325^{\circ} \mathrm{C}$ and returns to the holding tank. The furnace shown in Figure 1 is used only during start up to heat the salt.

\section{Plant Operation}

The Monsanto phthalic anhydride plant has been in operation since 1971 with no incidents of unscheduled downtime attributed to the molten salt portion of the facility. Every six months a scheduled maintenance is implemented to change-out of the bearings on the pump agitator and replacement of the catalyst pellets. The plant operator was able to recall only one unscheduled shutdown due to a tube break in the steam generator that was caused by corrosion on the water side.

Salt

The salt composition is HITEC with a total inventory of 125,000 lb. The salt temperature never exceeds $480^{\circ} \mathrm{C}$, the hottest spot in the chemical reactor. A nitrogen blanket is used to help maintain the salt composition. Salt samples are taken every three months for chemical analyses of oxide, carbonate, nitrite, and nitrate. Typical impurity levels are 0.03-0.05 


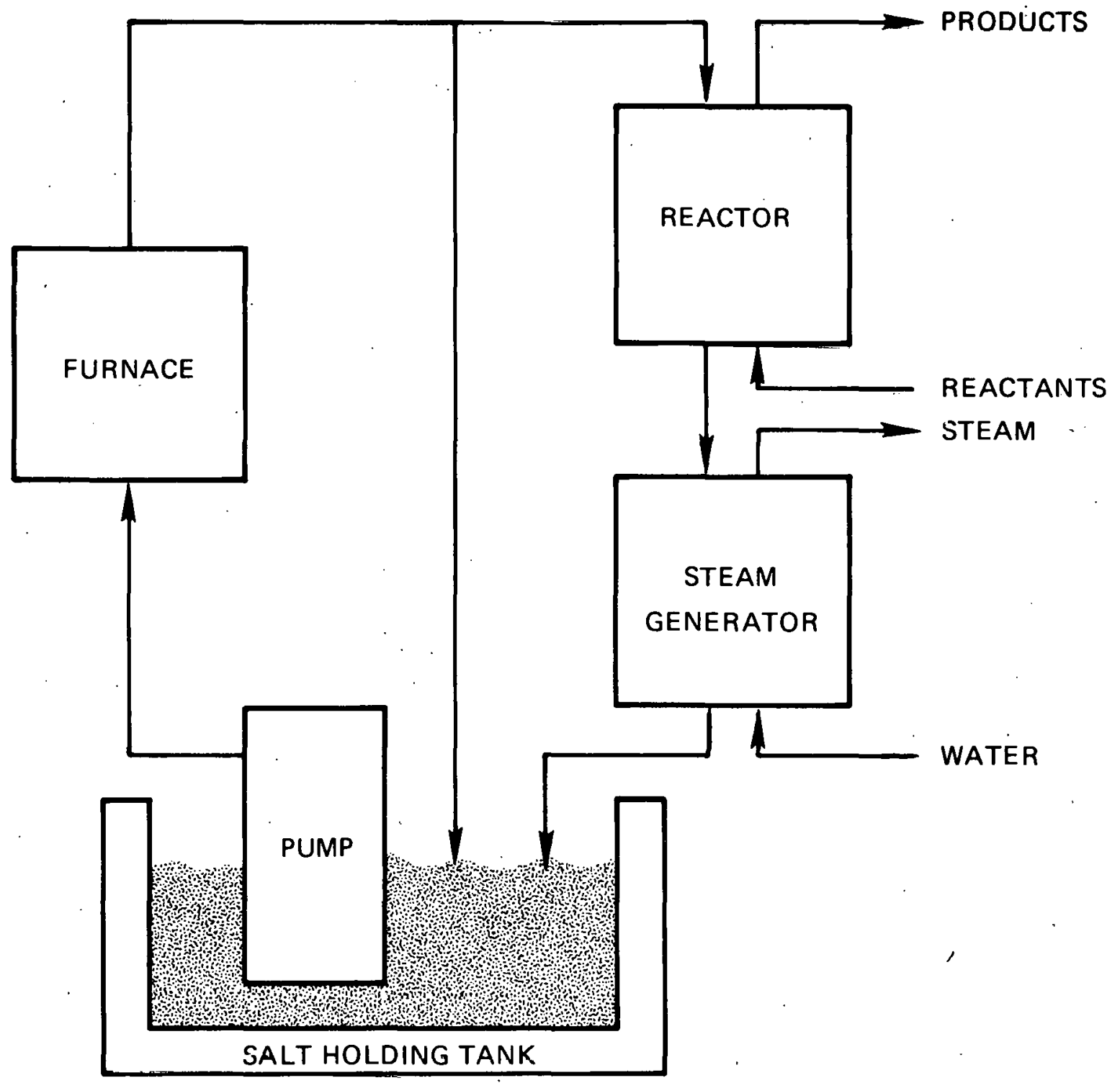

Figure 1. Circulating Molten Salt System for Heat Removal From an Exothermic Chemical Reactor. 
below a certain level additional salt is added. Between 300 to 400 pounds of make-up salt are required every year. The plant operators feel the major cause of salt loss is not thermal decomposition or vaporization but rather the physical loss of salt through small leaks and cracks. Molten nitrates have a propensity to creep and wet all materials and the smallest flaws in the system serve as salt leak paths. A visual inspection of the plant revealed several places of salt leakage and accumulation. In most cases, solidified salt either retarded the leakage rate or plugged the leak entirely.

\section{Containment Materials}

The entire molten salt loop system was constructed of carbon steel and no evidence of corrosion caused by the molten salt was seen. The only documented salt/materials problem was with the bearing on the pump agitator, and this part was simply changed out every six months.

$$
\text { Maleic Anhydride - Reichold Chemical }
$$

\section{Process Description}

Maleic anhydride is an organic chemical whose major use is in the synthesis of polyesters, alkyd resins, plastics, and agricultural chemicals. Maleic anhydride is synthesized in much the same manner as phthalic anhydride, by the catalytic vapor phase oxidation of organic molecules. Benzene and butylene are used for maleic anhydride synthesis. Many maleic anhydride plants are no longer in operation due to a diminished market demand, and flowing molten salt heat transfer systems no longer play a key role in the production because of the development of a more cost-effective batch process. The Reichold Chemical Company operated a maleic anhydride plant in Elizabeth, New Jersey, for many years but closed down the operation in 1979. The plant was, however, still intact and the plant manager was receptive to discussing their experience with salt.

Figure 1 is also applicable to maleic anhydride production. The synthesis is carried out in a tube and shell heat exchanger reactor with the tubes filled with catalyst pellets. The molten salt flows in the opposite direction of the reactant/product gas stream on the shell side of the tubes. Salt exits from the reactor at $\sim 400^{\circ} \mathrm{C}$, and is used to generate $225-250 \mathrm{psia} / 200-205^{\circ} \mathrm{C}$ steam. In the steam generator salt flows through u-shaped tubes with water/ steam in the shell. Salt exits the steam generator unit at $210^{\circ} \mathrm{C}$ and returns to the holding tank.

Salt is pumped from the holding tank with a Byron-Jackson centrifugal pump, rated at $3800 \mathrm{gal} / \mathrm{min}$ with an outlet pressure of $33 \mathrm{psia}$. Trace heating was provided by means of externally-located, steam-heated lines. Where flanged joints were used, metal 0-ring gaskets were found to be suitable. 


\section{Plant Operation}

The Reichold maleic anhydride plant was constructed in 1960 and operated until 1979. Reichold's experience with nitrate salts dates back to 1947 when first-generation, salt-cooled chemical reactors were built. The current plant was designed for continuous isothermal operation and the plant manager estimated the average unscheduled downtime was two days per year. Two reasons for unscheduled downtime were market surpluses of maleic anhydride and leaks in steam tubes (caused invariably by water-side corrosion).

The plant manager commented that the flowing salt system was the least troublesome of their heat exchange systems at the Elizabeth site. The time of greatest concern was plant.start-up, and measures to guard against freezing and plugging were required. This problem was solved quite simply by making sure the salt was hot before pumping it through the loop.

Salt

The salt inventory is 150,000 pounds, and flow rates of $3000-4500 \mathrm{gal} /$ min are used. The original salt composition used to charge the system was a binary mixture of 55 percent $\mathrm{NaNO}_{2}-45$ percent $\mathrm{KNO}_{3}$ by weight. A gas cover mixture of $\mathrm{CO}_{2}$ and $\mathrm{N}_{2}$ is used to blanket the salt. This particular gas composition was selected because it is available as a gaseous by-product from another process on site.

The melting point of the salt is used to monitor the salt. With time, the melting point drifts upward, and when it reaches $195^{\circ} \mathrm{C}, \mathrm{KNO}_{2}$ is added. The addition of $\mathrm{KNO}_{2}$ is required every five years. The $\mathrm{pH}$ is al so measured periodically (every three months) to guard against $\mathrm{OH}^{-}$corrosion and embrittlement. When the salt becomes too alkaline, $\mathrm{K}_{2} \mathrm{Cr}_{2} \mathrm{O}_{7}$ is added to neutralize it.

\section{Containment Materials}

The entire system was fabricated out of mild steel and corrosion problems have been limited to the water-side of the system. Some steam leaks have occurred due to corrosion of highly-stressed, hairpin-shaped steam tubes. An unusual pitting corrosion problem occurred when a salt leak saturated a ceramic insulation material that was in direct contact with the exterior surface of a mild steel pipe. The cause and mechanisms of this type of corrosion were not determined but it appears that complex corrosion chemistry takes place between the salt, a ceramic, and metal. 
Sodium Nitrate - 01 in Chemical

\section{Process Description}

$\mathrm{NaNO}_{3}$ is used for a multitude of purposes, the most extensive being in the agricultural, explosives, and glass industries. It can be synthesized by the reaction of nitric acid with caustic soda or sodium carbonate. The product of these reactions is a solution of $\mathrm{NaNO}_{3}$ in water; the water must be driven off to form anhydrous $\mathrm{NaNO}_{3}$.

The 01 in Company is the sole domestic producer of $\mathrm{NaNO}_{3}$. A simplified schematic of the molten salt portion of the 01 in plant in Lake Charles, Louisiana is shown in Figure 2. The feedstock is a 64 percent $\mathrm{NaNO}_{3}$ solution that enters a natural gas-fired flash evaporator. The feed enters at $100^{\circ} \mathrm{C}$ and molten $\mathrm{NaNO}_{3}$, with trace $\mathrm{H}_{2} \mathrm{O}$, exits at $342^{\circ} \mathrm{C}$. The maximum temperature in the gas-fired evaporator is believed to be $\sim 450^{\circ} \mathrm{C}$. The molten $\mathrm{NaNO}_{3}$ is dumped into an 80-ton capacity receiving pot which keeps a secondary salt pot heated. Salt is pumped from the 80-ton receiver pot to a vacuum drier where the remaining traces of $\mathrm{H}_{2} \mathrm{O}$ are driven off. Anhydrous mol ten $\mathrm{NaNO}_{3}$ is returned to a secondary receiver pot where it is held en route to pumping to the prill tower. At this point, the molten salt is $326^{\circ} \mathrm{C}$.

Two pumps are used in the system, one to pump the salt to the vacuum dryer, and a second pump to transport the salt to the prill tower. Both pumps are Lawrence vertical cantilever pumps with rated speeds of $287 \mathrm{gal} / \mathrm{min}$ and $90^{\prime}$ heads.

Trace heating features were not designed into this plant. During start-up, precautions are taken to ensure that the molten salt is heated to $380-400^{\circ} \mathrm{C}$ prior to pumping through the system. Salt at these temperatures is hot enough to avoid freezing problems. The entire system is gravity drained during shutdowns.

Pipe joins are generally made with metal 0-ring sealed flanges. Several valves in the system get heated to temperatures up to $342^{\circ} \mathrm{C}$. Asbestos graphiteimpregnated packings are used and are replaced every two years. These valves are not used for control purposes but rather for occasional open/close operations. Under normal conditions the valves are frozen open or closed and they are freed for use by heating with a torch.

\section{Plant Operation}

The 01 in plant is designed for continuous operation. It became operational in 1955 and has been operating without a major failure since then. A plant shutdown is scheduled once a year for maintenance. However, the plant records suggested actual downtime to be 1-2 days per month due to an assortment of reasons, including power outages, cleaning off the rakes in the prill tower, pump bearings replacement, and lack of market demand for the product. 


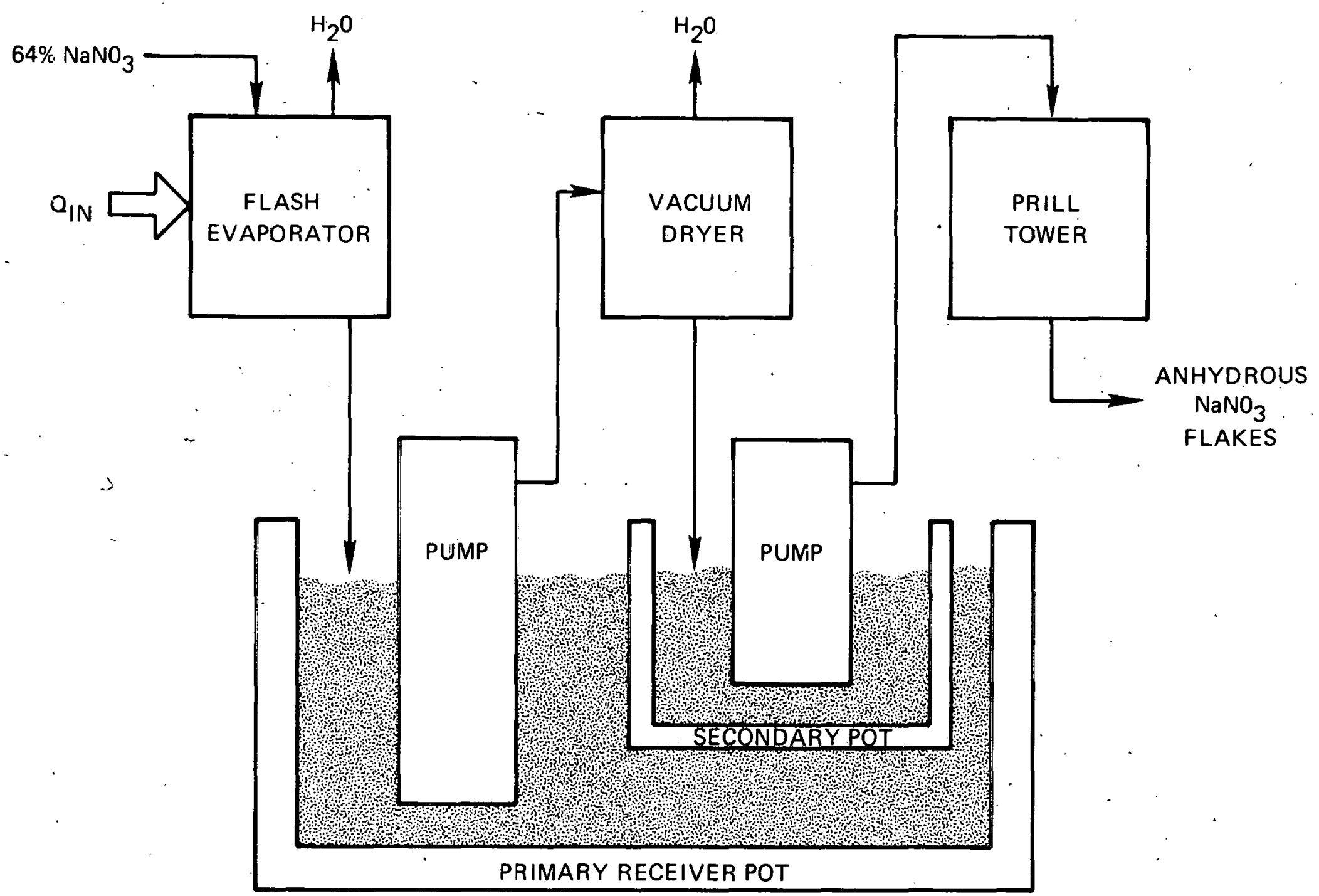

Figure 2. Portion of a $\mathrm{NaNO}_{3}$ Synthesis Plant. 
On-site welding is often used for repairs. If cracks are found through visual inspection during routine maintenance shutdown, the cracks are washed out and welded over. If pipes become clogged, a hole is cut into the pipe, the salt flushed out with water, and the pipe repaired by a welded patch.

Salt

The plant produces $\mathrm{NaNO}_{3}$ with portions of the product diverted for use as the heat transfer fluid. The maximum temperature of the salt is $\sim 450^{\circ} \mathrm{C}$, the hottest spot in the flash evaporator. Salt temperatures in most of the plant are less than $350^{\circ} \mathrm{C}$. The salt is constantly exposed to air and no effort is made to use an inert cover gas or to remove potentially harmful species such as $\mathrm{H}_{2} \mathrm{O}$ and $\mathrm{CO}_{2}$.

Containment Materials

The bulk of the system was constructed out of carbon steel, with the exception of a portion of the flash evaporator that was made of 310 stainless steel and some 304 piping. There has never been a documented incident of corrosion in the plant. As a result, no effort is made to monitor corrosion during plant operation.

The plant shuts down once a year for routine maintenance, at which time a careful inspection of metallic components of the flash evaporator is conducted. The gas piping at the top of the evaporator has a history of developing fatigue cracks due to cyclic thermal expansion. Approximately every two years repairs are made by cleaning the cracks and welding over them.

\section{Caustic Concentrator - 01 in Chemical}

\section{Process Description}

Caustic soda ( $\mathrm{NaOH})$ is a versatile chemical with widespread application, including organic and inorganic chemical production, and use in the petroleum, food processing, pulp and paper, and soap and detergent industries. $\mathrm{NaOH}$ and chlorine are produced by the electrolysis of sodium chloride in brine solutions. As might be expected, production of $\mathrm{NaOH}$ is heavily tied to the chlorine market. The product of the electrolys is reaction is a $\mathrm{NaOH}-\mathrm{H}_{2} \mathrm{O}$ solution, which is dried to 73-percent $\mathrm{NaOH}$ by using steam heated coils. The remaining water is driven off at higher temperatures by indirect contact with hot molten salt.

The heart of the system is a counterflow shell and tube heat exchanger where indirect contact is made between the salt and $\mathrm{NaOH}$ (Figure 3 ). Molten salt is pumped from a holding tank to a gas-fired furnace where it is heated to $400^{\circ} \mathrm{C}$. The hot salt enters the evaporator at the top and exits at $345^{\circ} \mathrm{C}$. The salt returns to the holding tank through a one-inch diameter orifice that serves as the flow controller. Anhydrous molten $\mathrm{NaOH}$ exits the concentrator at $\sim 370^{\circ} \mathrm{C}$ and is solidified on a flaking drum. 


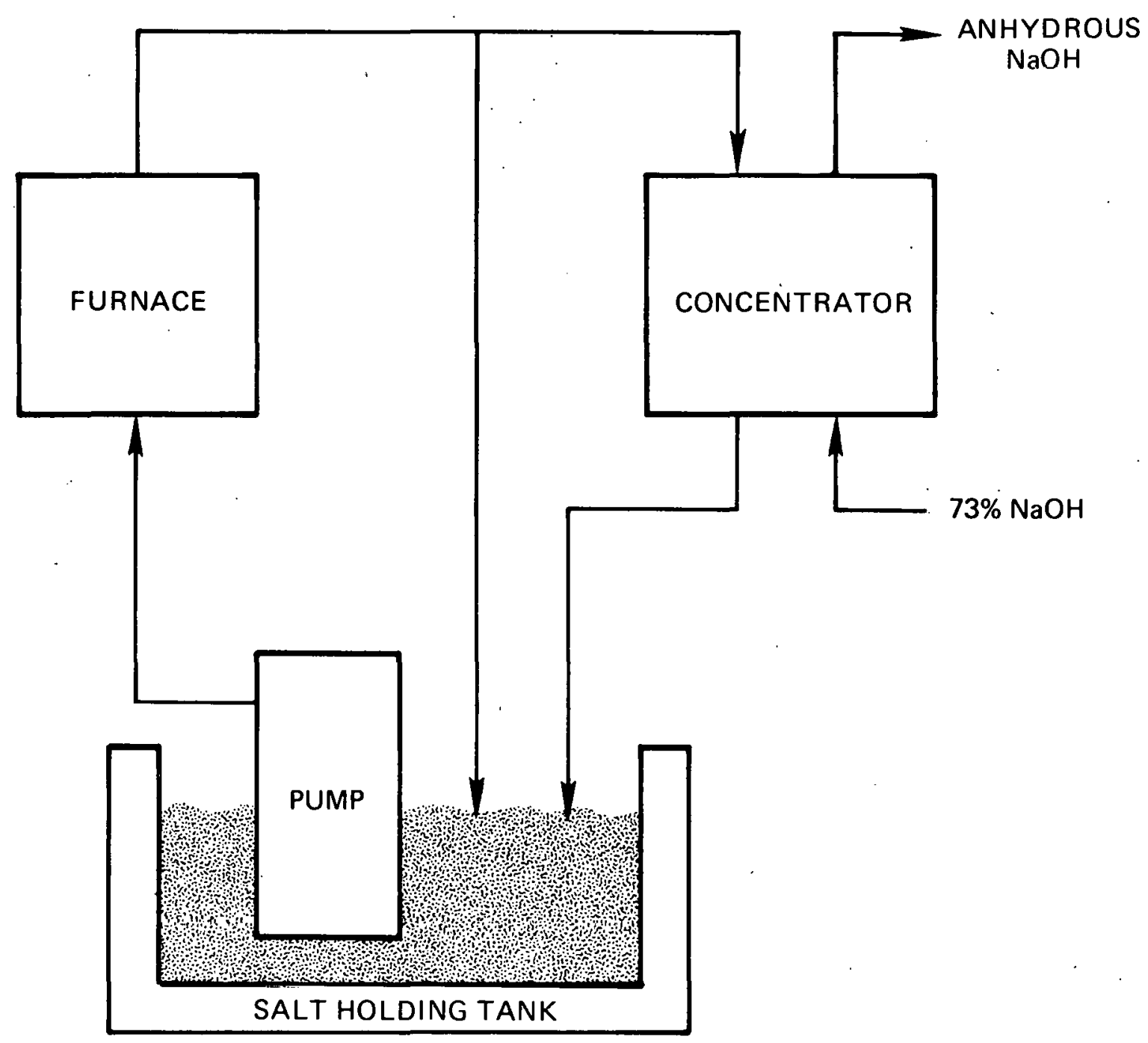

Figure 3. Caustic Concentration System Using a Pumped Molten Salt 
The 01 in plant utilizes a $111-g a l / m i n$ vertical cantilever pump with a seven-foot head. The pump has been operating since 1973 and has been repaired only once.

The plant was designed with bellows to handle thermal expansion, and pipes were joined with metal 0-ring joints. Steam lines held in external contact with the pipes served as the trace heaters.

\section{Plant Operation}

The 01 in caustic concentrator salt loop has been in operation since 1973 . The system operates continuously under isothermal conditions. Every nine months the operation is shut down for routine maintenance at which time the heat exchange tubes are either inverted or replaced as a precaution against contamination of the product stream.

While continuous operation is desirable, the actual operating schedule is determined by market demand for chlorine and $\mathrm{NaOH}$. For example, between April 1975 to December 1977 the plant schedule was ten days on, four days off. Unscheduled shutdowns occurred with frequencies of one or two times a month, but were never attributed to the molten salt system. Generally, unscheduled shutdowns were caused by concerns of materials and components in direct contact with the caustic.

Salt

The salt used in this system is HITEC with a total capacity of 26,400 pounds. Salt is indirectly heated to $400^{\circ} \mathrm{C}$ in a natural gas furnace and exits the concentrator at $345^{\circ} \mathrm{C}$. Changes in the salt chemistry are monitored by measuring the melting point. Samples are taken every week for a melting point determination. If the melting point rises to more than $151^{\circ} \mathrm{C}$ (from an initial value of $141^{\circ} \mathrm{C}$ ) additional HITEC is added to the system. Approximately $400 \mathrm{lb}$ of salt are added each month.

A nitrogen cover gas is used to blanket the salt. A slight positive pressure is maintained as $N_{2}$ continually purges the system.

In addition to monitoring the melting point, the salt level in the holding tank is recorded periodically as a back up indicator of salt depletion. The primary mode of salt loss appeared to be physical loss due to creeping through leaks and cracks.

\section{Containment Materials}

Mild steel was the material of construction throughout, with the exception of the tubes carrying $\mathrm{NaOH}$ in the concentrator heat exchanger. These tubes were fabricated out of Inconel 600 because of compatibility with $\mathrm{NaOH}$. No evidence of corrosion caused by nitrate salts was ever observed. 
Melamine - Anonymous

\section{Process Description}

Melamine is an organic compound used for making amino resins and plastics. The most common method of production is the endothermic break down of urea to carbon dioxide, ammonia, and cyanamide. The cyanamide trimerizes to melamine in an atmosphere of ammonia. A biproduct of melamine is ammonium carbonate which is recycled and converted to urea. For this reason melamine production is usually integrated with much larger facilities producing ammonia and urea.

Salt is heated by a gas-fired heater to about $435^{\circ} \mathrm{C}$. The heated salt is then pumped through coiled tubes in a fluidized bed reactor. The pump is a Lawrence vertical cantilever type rated at 3400 to $3600 \mathrm{gal} / \mathrm{min}$. Pipe external to the fluidized bed reactor are trace heated with steam. Flanged piping is joined with stainless steel 0-rings.

\section{Plant Operation}

The melamine plant has been in operation for about ten years. The 316 stainless steel impeller and bearings of the salt pump are partially rebuilt every two years because of gradual erosion. General chemical corrosion has never been evident. Problems with welding of carbon steel pipes after exposure to molten salt have been experienced. It was found that the pipes must be washed out with great care with hydrochloric acid prior to welding.

$\underline{\text { Salt }}$

The salt composition is HITEC with a temperature design limit of $450^{\circ} \mathrm{C}$ in the salt heater. Originally, air was used as the cover gas over the salt. The melting point of the salt was observed to increase with time to such an extent that a complete change out of salt was made every one to two years. Carbonate sludge was also detected in low velocity areas of the system. More recently a nitrogen cover gas has been used which has eliminated the need to completely replace the salt.

\section{Containment Materials}

All piping external to the reactor and not in contact with ammonia was constructed of carbon steel. The molten salt piping in the reactor and the ammonia/molten salt heat exchanger were constructed of Hastelloy 6 and C276. General corrosion was not a concern. 
Metals Treating - McDonnell Douglas

Process Description

The McDonnell Douglas Astronautics Company operates a metals heat treatment facility as part of their aircraft repair and modification facility. Thi.s facility includes a high-temperature heat treatment bath for solution heat treating of aluminum alloy extrusions and forgings. The salt bath tank measures $4 \mathrm{ft}$ wide $\times 20 \mathrm{ft}$ long $\times 6 \mathrm{ft}$ deep, and the salt medium is heated electrically with copper electrodes.

During startup, salt is packed around the electrode and heated with a hand-held torch to generate an electrically-conducting melt. After a minimum amount of fluid electrolyte is formed, electric current is passed between the electrodes to provide the melt energy for additional salt. The salt bath is maintained at 470 to $525^{\circ} \mathrm{C}$ depending upon prescribed heat treatments.

Plant Operation

The heat treatment facility has been in operation since 1951. The salt tank is drained completely every ten years and is inspected for corrosion and wear. The operator considered the heat treating facility to be "maintenance free." The most serious problem experienced to date was the breakdown of the ceramic liner of the tank cover.

Salt

The salt composition is a binary mixture of $\mathrm{NaNO}_{3}$ and $\mathrm{KNO}_{3}$. The salt inventory is 54,000 lbs and it is opened to the air. Periodic checks are made every three months for 1 iquid level and $\mathrm{pH}$. Two to four barrels of salt ( 400 lbs of salt per barrel) are added every three months to replace the salt lost because of drag out. If the $\mathrm{pH}$ is too alkaline, $\mathrm{Na}_{2} \mathrm{CrO}_{4}$ is added. sludge builds up in the bottom of the tank and is attributed to scaling from the treated metal parts.

Containment Materials

The salt tank is a ceramic-insulated tank with an inner liner of $3 / 4$ inch thick carbon steel. After operating for 20 years, several areas in the tank wall had thinned to unacceptable thicknesses, as determined during a scheduled shutdown. These thinned places were reinforced on the insulation side, and the patched tank has been in service for $\sim 10$ years. 
Others

The industrial applications previously described are well-known large scale uses of molten nitrate salts with years of operation. There are undoubtedly many molten salt operations that are smaller in scale, unique, and/ or not widely known to the general public. For one example, it was drawn to our attention that the Intenco Company uses a molten salt loop in a hightemperature pyrolysis pilot plant. Worn rubber tires are pyrolyzed to useful products by indirect heating with molten nitrates. The heart of the Intenco System was a 30,000 1b capacity American Hydrotherm 7 system. Salt is heated to $552^{\circ} \mathrm{C}$ by means of several immersion ram heaters and is then pumped to two pyrolyzers at a rate of $180 \mathrm{gal} / \mathrm{min}$. A vertical cartilever pump is used. The initial salt composition was HITEC. Air was not excluded from the system and therefore the actual salt composition has most probably deviated from the original HITEC composition. No efforts were made to monitor and/or control the salt chemistry. Salt exits the reactors at $\sim 510^{\circ} \mathrm{C}$ and is returned to the holding tank. 304 stainless steel was used for construction.

The Intenco pilot plant has been in operation for only a few years It was designed to test and evaluate a potential commercial process. The plant start-up date was 1978. Because of the experimental nature of this pilot plant, the operational life has been limited. The plant operator estimated the total full-capacity operating time at 8,000-10,000 hours. As was true with all of the plants visited, the Intenco plant engineers were not overly concerned over the operation of a hot molten salt system.

\section{Application of Industrial Experience to Solar Systems}

Discussions with industrial users of molten nitrates and visitations to various industrial plants all point to the same conclusion: molten nitrate salt systems were generally the subsystems of least concern. Trouble-free operation was a ruie. Operational procedures for start-up, shutdown, and maintenance were easily implemented. Monitoring the salt system requires a minimal effort; it was sufficient to monitor the salt temperature in various strategic locations and/or periodically sample the salt for a melting point determination. When emergency repairs were required, they were carried out in a routine fashion. The safety records for all plants were excellent; no serious accidents were ever attributed to the molten salt system.

While this industrial track record is encouraging, the applicability of this data base to solar large power systems must be assessed. Key differences are the temperature of operation, isothermal versus cyclic operation, the salt composition, and the system capacity.

Generally, industrial experience is limited to temperatures below $450^{\circ} \mathrm{C}$. Solar systems can expect to operate at bulk salt temperatures of $565^{\circ} \mathrm{C}$ al though temperatures as high as $590^{\circ} \mathrm{C}$ can be expected in certain areas of the system. Therefore, there is no relevant temperature experience. This has direct impact on the materials of construction and salt compositions. 
Industrial applications are generally isothermal by design. It is recognized that chemical reactors should be operated in an isothermal mode in order to el iminate materials problems and to increase process efficiency and component lifetimes. Solar energy is cyclic by nature. At a minimum, the cycles are diurnal, and imposed upon diurnal cycles are shorter term transients due to cloud coverage. Thermal cycling is at its worst in the solar receiver; other parts of the system such as the thermal energy storage system are buffered.

With the relatively low-temperature requirements of industrial applications, HITEC is the salt composition of greatest use. However, binary drawsalt (or other $\mathrm{NaNO}_{3}-\mathrm{KNO}_{3}$ binary compositions) is the preferred nitrate salt composition for central receiver systems because HITEC has been found to be unstable at the temperatures of interest in solar energy systems. The nitrite constituent in HITEC is easily converted to the nitrate form. There has not been an extensive amount of industrial experience with binary nitrate salts. However, evidence suggests that binary nitrates offer some advantages over HITEC, as they appear to be less corrosive. 8

Industrial uses require relatively small amounts of salt when compared to large solar power system requirements. Industrial applications usually involve 50,000-200,000 pounds salt capacity whereas a 100-MWe solar plant with six hours of storage would require 150 million pounds of salt. Clearly there is no industrial experience with such copious quantities of salt. However, the sizes of certain components, for example pumps, required for solar applications may be very similar in size to those used in industry.

\section{Summary}

A study of different industrial uses of molten nitrate salts has been completed in which plant engineers and plant managers were contacted and their observations regarding operating history, procedures, and problems were solicited. This study also included on-site inspections of the plants and discussions with plant operating personnel. In all cases, molten nitrate salt systems operated without concern, and years of trouble-free operation was the rule. The operating parameters are generally different from those anticipated in solar thermal systems. As examples, the temperatures were lower, salt compositions different, thermal-time histories more benign, and system capacities smaller. These differences preclude the direct application of the industrial base of experience to solar thermal applications. However, the positive experiences to date should be encouraging to those developing nitrate-based solar thermal energy systems. 
REFERENCES

1. T. R. Tracey, "Conceptuál Design of Advanced Central Receiver Power system, Phase I Report," Martin Marietta final report for DOE Contract EG-77C-03-1724.

2. "Proceedings, DOE Large Solar Central Power Systems Semi-Annual Review," Sandia National Laboratories Report SAND80-8805, June 1980.

3. "Report on Design, Handling, Operation and Maintenance Procedures for HITEC Molten Salt," Sandia National Laboratories Report, SAND80-8179, January, 1981 (prepared by Badger Energy, Inc.).

4. V. W. Uhl and H. P. Voznick, Chem. Eng. Prog. 59, 33 (1963).

5. H. P. Voznick and V. W. Uh1, Chem. Eng., 70, 129 (1963).

6. J. R. Fried, Chem. Eng. 80,89 (1973).

7. Hydrotherm Molten Salt Heat Transfer System, American Hydrotherm Corp., 470 Park Avenue South, New York, N.Y. 10016.

8. R. W. Bradshaw, Sandia National Laboratories, Livermore, CA. (private communication). 


\section{UNLIMITED RELEASE}

\section{INITIAL DISTRIBUTION}

Division of Thermal and Mechanical Energy Storage Systems

MS 6B025 Room $1 \mathrm{G}-100$

Forrestal Building

U.S. Department of Energy

Washington, D. C. 20585

Attn: M. Gurevich

S. Strauch

J. H. Swi sher

Division of Solar Thermal Energy Systems

600 E Street N.W., Room 419

U.S. Department of Energy

Washington, D.C. 20585

Attn: W. Auer

G. W. Braun

C. Manngold

C. McFarland

J. E. Rannels

D. Stogoski

Albuquerque Operations office

Special Programs Division

P. 0. Box 5400

U.S. Department of Energy

Albuquerque, NM 87115

Attn: D. Schueler

San Francisco Operations office

1333 Broadway

U.S. Department of Energy

Oakl and, CA 94612

Attn: D. Elliott

Dr. Robert A. Usteryoung

Department of Chemistry

State University of New York at Buffalo

Buffalo, NY 14214

Prof. Harald A. Oye

Institutt for uorganisk kjemi

Norges tekniske hogskole

Universitetet $i$ Trondhe im

N-7034 Trondheim - NTH

NORWAY

John Neill

Advanced Energy Concepts

Suite I

11722 Sorrento Valley Rd.

San Diego, CA 92121 
T. V. Narayanan

Foster Wheeler

12 Peach Tree Hill Road

Livingston, NJ 07039

Aerospace Corporation 2350 El Segundo Blvd.

El Segundo, CA 90009

Attn: P. Mathur

L. R. Sitney

Steve P. Harnden

Arizona Public Service Company.

P. 0. Box 21666

Phoenix, AZ 85036

William F. Clancey

Babcock and Wilcox Company

P. 0. Box 351

Barberton, $\mathrm{OH} 44203$

Bill Oberjohn

Babcock and Wilcox

Box 835

Alliance, $\mathrm{OH} \quad 44601$

C. A. Bolthrunis

Badger Energy, Inc.

One Broadway

Cambridge, MA 02142

Robert L. Lessley

Bechtel

50 Beale

San Francisco, CA 94119

James $P$. Maddox

Biphase Energy Systems

2800 Airport Ave.

Santa Monica, CA 90405

George H. Rowe

Combustion Engineering

1000 Prospect Hill Road

Windsor, CT 06095

Sydney H. White

EIC Labs., Inc.

55 Chapel Street

Newton, MA 02158 


\section{EPRI}

P. 0. Box 10412

3412 Hillview Ave.

Palo Alto, CA 94303

Attn: J. Bigger

Donald C. Erickson

Energy Concepts Co.

627 Ridgely

Annapolis, MD, 21401

Patrick Joy

Sol ar Thermal Systems

Divisin of Exxon Enterprises, Inc.

P. 0. Box 592

Fiorham Park, NJ 07932

T. V. Narayanan

Foster Wheeler

12 Peach Tree Hill Road

Livingston, NJ 07039

Donald J. Spel Iman

Gas Cooled Reactor Assoc.

3344 N. Torrey Pines Road

La Jolla, CA. 92137

General Atomic Co.

P. 0. Box 81608

San Diego, CA 92138

Attn: James Kaae

Daniel L. Vrable

J. H. DeVan

Oak Ridge National Laboratory

Oak Ridge, TN 37830

Soeren S. Nielsen

Gould, Inc.

40 Gould Center

Rolling Meadows, IL 60008

Alan Snelson

ITT Research Institute

10 W 35 Street

Chicago, IL 60616

$\mathrm{JPL}$

4800 0ak Grove Dr.

Pasadena, CA 91103

Attn: J. Becker

V. Truscello 
Martin Marietta Corporation

Box 179

Denver, CO 80201

Attn: David W. Neiswander Tom Tracey

McDonnel 1 Douglas

5301 Bol sa Ave.

Huntington Beach, CA 92647

Attn: Donald L. Endicott

George F. Greenwald

C. M. Kramer

Code 6130

Naval Research Lab

Washington, D. C. 20375

j. H. DeVan

Oak Ridge National Laboratory

Oak Ridge, TN 37830

01 in Corporation

275 Winchester Ave.

New Haven, CT 06511

Attn: Louis C. Fiorucci

Stephen L. Goldstein

01 in Corporation

120 Long Ridge Road

Stamford, CT 06904

Attn: Norman Christopher

Pacific Gas and Electric

3400 Crow Canyon Road

San Ramon, CA 94583

Attn: Jay Raggio

Dr. R. W. Foreman

Park Chemical Company

8074 Military Avenue

Detroit, MI 48204

Robert J. Walter

Rocketdyne

6633 Canoga Ave.

Canoga Park, CA 91360

Rockwell International

8900 Ue Soto Ave.

Canoga Park, CA. 91304

Attn: Jerry B. Brukiewa, ETEC

Rick L. Howerton, ETEC

Ted Johnson, ESG

Anarg Z. Frangos 


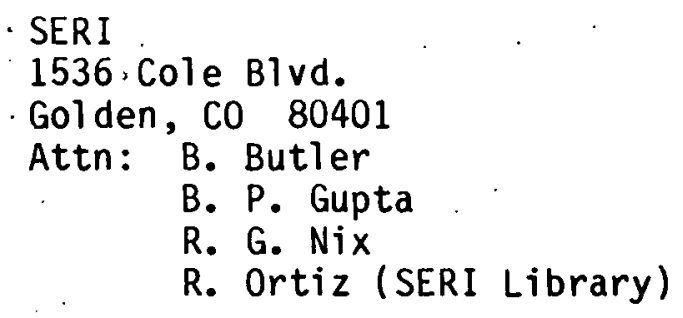

Kenneth Ladd

Southwestern Public Service Co.

P. 0. Box 1261

Amarillo, TX 79170

Donald J. Liffengren

Stearns-Roger

- 4500 S. Cherry Creek Drive

Denver, CO 80217

United Engineers and Construction

$30 \mathrm{~S}$. 17 th Street

Philadelphia, PA 19103

Attn: A. E. Rosica

Niven D. Morgan, Jr.

Suite 241

Vertac Chemical Corporation

3000 Knight office Place

Shreveport, LA 71105

Stuart A. Shiels

Westinghouse Electric Corporate

Advanced Reactors Division

Box 158

Madison, PA 15663

C. Winter, 400

A. Narath, 4000

J. H. Scott, 4700

G. E. Brandvold, 4710; Attn: R. P. Stromberg, 4714

J. F. Banas, 4716

J. A. Leonard, 4717

D. G. Schueler, 4720; Attn: J. V. Otts, 4721

J. K. Galt, 5000

R. S. Claassen, 5800

R. G. Kepler, 5810

M. J. Davis, 5830; Attn: R. W. Rohde, 5832

N. J. Magnani, 5840

T. B. Cook, 8000; Attn: D. M. 01 son, 8100

W. E. Al zheimer, 8120; Attn: R. J. Gallagher, 8124

A. N. Blackwell, 8200

B. F. Murphey, 8300

D. M. Schuster, 8310

R. W. Bradshaw, 8313

R. W. Mar, 8313 (5) 
D. A. Nissen, 8313

S. H. Goods, 8316

J. C. Swearengen, 8316

R. L. Rinne, 8320

L. Gutierrez, 8400

R. A. Baroody, 8410

R. C. Wayne, 8430

R. W. Carling, 8431 (5)

P. J. Eicker, 8431

L. G. Radosevich, 8431

C. S. Selvage, 8450

C. T. Yokomizo, 8451

A. C. Skinrood, 8452

D. B. Dawson, 8453

W. G. Wil son, 8453

C. M. Tapp, 8460

D. L. Hartiey, 8500

Publications Division, 8265, for TIC (27)

Publications Division, 8265/Technical Library Processes Division, 3141

Technical Library Processes and Systems Division, 3141 (3)

M. A. Pound, 8214, for Central Technical Files (3) 
